\title{
INSETICIDAL OILS FROM AMAZON PLANTS IN CONTROL OF FALL ARMYWORM ${ }^{1}$
}

\author{
ANA CLÁUDIA VIEIRA DOS SANTOS ${ }^{2}$, CARROMBERTH CARIOCA FERNANDES ${ }^{3}$, LUCAS MARTINS LOPES ${ }^{2}$, \\ ADALBERTO HIPÓLITO DE SOUSA ${ }^{3 *}$
}

\begin{abstract}
The potential insecticidal of oils from southwestern Amazon plants against Spodoptera frugiperda (J. E. Smith, 1797) (Lepidoptera: Noctuidae) was investigated. Initial bioassays were performed with undiluted oils from 11 plant species. The efficacy of the oils was evaluated against eggs and third-instar caterpillars of $S$. frugiperda. The oils of Copaifera sp. (Leguminosae), Orbignya phalerata (Arecaceae), and Carapa guianensis (Meliaceae) displayed a high efficacy against the caterpillars and were used in subsequent concentration-response bioassays, at concentrations established through preliminary tests. The highest nonlethal concentrations of oils and the lowest lethal concentrations were calculated. A completely randomized design was adopted in both bioassays. The $\mathrm{LC}_{50}$ of the oils varied from 7.50 to $60.84 \%$ (v/v). Copaifera sp. oil had the highest toxicity and was 6.84 -fold more toxic than $O$. phalerata oil and 8.11 -fold more toxic than Carapa guianensis oil. In general, oils from Copaifera sp., O. phalerata, and Carapa guianensis were effective in controlling S. frugiperda caterpillars under laboratory conditions, and are good candidates for use in integrated management programs of corn pests.
\end{abstract}

Keywords: Spodoptera frugiperda. Botanical insecticides. Carapa guianensis. Copaifera sp. Orbignya phalerata.

\section{ÓLEOS INSETICIDAS DE PLANTAS DA AMAZÔNIA NO CONTROLE DA LAGARTA-DO- CARTUCHO}

RESUMO - Investigou-se o potencial inseticida de óleos vegetais de plantas ocorrentes na Amazônia Sul Ocidental sobre Spodoptera frugiperda (J. E. Smith, 1797) (Lepidoptera: Noctuidae). Inicialmente, foram realizados bioensaios utilizando-se óleos puros (sem diluições), oriundos de 11 espécies vegetais. A eficiência dos óleos foi avaliada para ovos e para lagartas de terceiro ínstar de S. frugiperda. Os óleos de Copaifera sp. (Leguminosae), Orbignya phalerata (Arecaceae) e Carapa guianensis (Meliaceae) apresentaram elevada eficiência para as lagartas de $S$. frugiperda, sendo, portanto utilizados nos bioensaios subsequentes de concentração-resposta. As concentrações de cada óleo, utilizadas nestes testes de concentração-mortalidade, foram estabelecidas por meio de testes preliminares. Estabeleceram-se as maiores concentrações dos óleos em que não ocorresse morte de insetos e as menores concentrações em que ocorresse a maior mortalidade. Com base nos dados obtidos, foram estabelecidos os intervalos definitivos. O delineamento inteiramente casualizado foi adotado em ambos os bioensaios. As $\mathrm{CL}_{50}$ variaram de 7,50 a $60,84 \%(\mathrm{v} / \mathrm{v})$ entre os óleos. O óleo de Copaifera sp. apresentou maior toxicidade para as lagartas, sendo 6,84 vezes mais tóxico que o óleo de $O$. phalerata e 8,11 vezes mais tóxico que o óleo de Carapa guianensis. Em geral, os óleos de Copaifera sp., $O$. phalerata e Carapa guianensis são eficazes no controle de lagartas de S. frugiperda, sob condições de laboratório, destacando-se como candidatos a uso nos programas de manejo integrado das pragas do milho.

Palavras-chave: Spodoptera frugiperda. Inseticidas botânicos. Copaifera sp.. Orbignya phalerata. Carapa guianensis.

\footnotetext{
*Corresponding Author

${ }^{1}$ Received for publication in $05 / 01 / 2015$; accepted in 04/11/2016.

Part of the Master's Dissertation of the first author.

${ }^{2}$ Posgraduate Program in Plant Production (Agronomy), Universidade Federal do Acre, Rio Branco, AC, Brazil; anavieira-85@hotmail.com, lucas_lopes_17@hotmail.com.

${ }^{3}$ Center for Biological and Natural Sciences, Universidade Federal do Acre, Rio Branco, AC, Brazil; carromberth@bol.com.br, adalberto@ufac.br.
} 


\section{INTRODUCTION}

Production from Brazilian agriculture, primarily grains, has been increasing, owing to investments in new planting and harvesting technologies (ALVES et al., 2012). According to the National Resource Company (Companhia Nacional de Abastecimento, CONAB), the estimated Brazilian production of grain in the 2015-2016 harvest will be 210.3 million tons, with corn representing $40.93 \%$ of total production, around 83,519.1 million tons (CONAB, 2016).

One of the primary factors in low corn production is the damage caused by insect pests, which can occur in the field as well as during storage (FARONI; SOUSA, 2006). Pest damage can compromise the grain yield and quality, causing serious losses for farmers (COPATTI; MARCON; MACHADO, 2013). The fall armyworm, Spodoptera frugiperda (J. E. Smith, 1797) (Lepidoptera: Noctuidae), is an important field pest, and the corn weevil, Sitophilus zeamais (Motschulsky, 1885) (Coleoptera: Curculionidae), is an important storage pest (CRUZ et al., 2013).

The fall armyworm ( $S$. frugiperda) may attack corn crops from seedling emergence to cob formation. It can cause high losses in grain productivity because the plants have no resistance to the pest (HAAS et al., 2014). Insecticides are applied in excess of the recommended dose during harvest in some regions in an effort to control this pest (FIGUEIREDO; MARTINS-DIAS; CRUZ, 2006).

Spodoptera frugiperda is normally controlled with synthetic insecticides; however, the use of these products has caused environmental contamination, human poisoning, extinction of natural predators, higher numbers of pests (MARTINS et al., 2009; LIMA JÚNIOR et al., 2010), and selection of resistant insects, requiring increasingly higher doses of insecticides (ALVES et al., 2012). Therefore, the search for alternative insecticides has become increasingly important.

Plants produce substances to defend themselves against insects, pathogens, and microorganisms (SOUSA; FARONI; FREITAS, 2014; ALVES et al., 2012). Secondary metabolites with insecticidal properties include terpenoids and limonoids, among others (SARRIA et al., 2011). These compounds may have different modes of action on insects; they may be acutely toxic, repellent, or inhibit feeding, growth, development, and reproduction. Plant-derived insecticides are usually available as powders, extracts, or oils, which are easy to obtain (GUERRA et al., 2009; HAAS et al., 2014; SOUSA; FARONI; FREITAS, 2014).

Given the problems associated with the use of synthetic insecticides in the control of $S$. frugiperda and considering the high plant diversity of the Amazon, the objective of this study was to determine the potential insecticidal activity of oils from plants occurring in the southwestern Amazon.

\section{MATERIAL AND METHODS}

Selective bioassays were performed by exposing the eggs and third-instar caterpillars of $S$. frugiperda to 11 undiluted oils. The most efficacious oils were evaluated with concentration-response bioassays to establish the degree of toxicity.

The bioassays were carried out in the Laboratory of Entomology of the Federal University of Acre, Rio Branco Campus, under constant temperature $\left(25 \pm 2^{\circ} \mathrm{C}\right)$ and relative humidity $(70 \pm$ $5 \%$ ), using biochemical oxygen demand-type incubators. A stock colony of S. frugiperda was established in the laboratory according to the methods of Bavaresco et al. (2002), from specimens from the Agroforestry Research Center of Acre (EMBRAPA/AC). The caterpillars were fed on a diet composed of ascorbic acid (5.1 g), sorbic acid (1.7 $\mathrm{g})$, agar $(15.0 \mathrm{~g})$, distilled water $(1,200.0 \mathrm{~mL})$, beans $(1,665.5 \mathrm{~g}), 10 \%$ formalin $(5.0 \mathrm{~mL})$, wheat germ $(79.2 \mathrm{~g})$, brewer's yeast $(50.7 \mathrm{~g})$, methyl parahydroxybenzoate (nipagin) (3.2 g), and inhibitor solution $(5.0 \mathrm{~mL})$. The diet was produced according to Kasten Júnior, Precetti and Parra (1978).

Oils were extracted from the seeds of Astrocaryum aculeatum G. Mey. (Arecaceae), Oenocarpus bataua Mart. (Arecaceae), and Orbignya phalerata Mart. (Arecaceae); fruit pulp of Mauritia flexuosa L. f. (Arecaceae) and Caryocar brasiliense Cambess. (Caryocaraceae); seeds from Anadenanthera colubrina (Vell.) Brenan (Fabaceae), Carapa guianensis Aubl. (Meliaceae), Platonia insignis Mart. (Clusiaceae), and Pentaclethra macroloba (Willd.) Kuntze (Fabaceae); leaves of Vernonia polysphaera (Asteraceae); and wood of Copaifera sp. (Fabaceae).

The oils of Platonia insignis, Pentaclethra macroloba, and A. aculeatum were purchased from producers in Santa Bárbara do Pará, Pará. The Pará municipality is located at $01^{\circ} 13^{\prime} 26^{\prime \prime}$ south latitude and $48^{\circ} 17^{\prime} 22^{\prime \prime}$ west longitude, on the borders of the Augusto Meira Filho PA-391 highway. The other oils were acquired from the Technology Foundation of the State of Acre (FUNTAC), from producers in the municipality of Rio Branco, Acre. The Acre municipality is located at $9^{\circ} 58^{\prime} 29^{\prime \prime}$ south and $67^{\circ}$ $48^{\prime} 36^{\prime \prime}$ west, at an altitude of 153 meters above sea level.

In the selective bioassays, each oil was tested on the eggs and third-instar caterpillars of $S$. frugiperda. The tests were performed in Petri dishes $(5.0 \mathrm{~cm}$ diameter $\times 1.2 \mathrm{~cm}$ height $)$ containing a filter paper disc moistened with $200 \mu \mathrm{L}$ of the oil; the oil quantity was determined in preliminary tests. Four Petri dishes were used as replicates for each egg bioassay and contained a disc with 40 eggs/plate. Four groups of 10 Petri dishes were used for each of 
the caterpillar bioassays, with only one caterpillar per plate to prevent cannibalism. A completely randomized design was used. Eggs and caterpillars were exposed to the oils for $24 \mathrm{~h}$. Subsequently, the numbers of hatched and unhatched eggs and live and dead caterpillars were counted. The egg count was repeated daily until the fifth day, as established in the preliminary tests.

The toxicity of Copaifera sp., O. phalerata, and Carapa guianensis oils was subsequently determined through estimates of lethal concentrations for $50 \%$ of the insects $\left(\mathrm{LC}_{50}\right)$. Initially, preliminary tests were performed to estimate the highest oil concentrations in which there were no insect deaths and the lowest concentrations in which the highest mortalities occurred. Five concentrations were established for the definitive bioassays with Carapa guianensis oil $(0,25,50,75$, and $100 \% \mathrm{v} / \mathrm{v})$, six for Copaifera sp. $(0,5,10,15$, 20 , and $25 \% \mathrm{v} / \mathrm{v})$, and six for $O$. phalerata oil $(0,20$, $40,60,80$, and $100 \% \mathrm{v} / \mathrm{v})$. The tests were performed in Petri dishes $(5.0 \mathrm{~cm}$ diameter $\times 1.2 \mathrm{~cm}$ height $)$ containing a disc of filter paper moistened with 200 $\mu \mathrm{L}$ of each oil at the previously established concentrations. The same experimental units as the selective bioassays were used. The caterpillar mortality rate was evaluated after $24 \mathrm{~h}$ of exposure to the oils.

The efficacy of the selective bioassay treatments compared to the controls was calculated with Abbott's formula. Data were evaluated with an analysis of variance (ANOVA) and the Scott-Knott test, with a significance level of $5 \%$. The analyses were conducted with the program SISVAR
(FERREIRA, 2011).

Bioassay mortality data to determine the toxicity of Carapa guianensis, Copaifera sp., and $O$. phalerata oils were submitted to a Probit analysis to generate concentration-mortality curves (PROC PROBIT; SAS INSTITUTE, 2011). The toxicity ratios (TR) were calculated as described in Robertson and Preisler (1992).

\section{RESULTS AND DISCUSSION}

A significant effect was observed for undiluted oils on $S$. frugiperda eggs $\left(\mathrm{F}_{10 ; 29}=7.04 ; P<0.001\right)$ and caterpillars $\left(\mathrm{F}_{10 ; 29}=27.59 ; P<0.001\right)$ (Table 1). The efficacy varied from 14.38 to $91.50 \%$ on the eggs and from 0 to $100 \%$ on the caterpillars. Most of the oils were similarly efficacious on eggs, although the $P$. macroloba and $O$. phalerata oils were less efficacious. The most efficacious oils against the caterpillars were obtained from Copaifera sp., $O$. phalerata, and Carapa guianensis.

The caterpillar $S$. frugiperda causes heavy economic losses in all crops that it attacks, so a highly and rapidly effective insecticide is desirable (ALVES et al., 2012). The Copaifera sp., $O$. phalerata, and Carapa guianensis oils were the most suitable in this study because they demonstrated moderate toxicity in $24 \mathrm{~h}$. In general, botanical insecticide efficiency may be associated with direct effects (caterpillar mortality) and indirect effects (increasing vulnerability to parasitoids, predators, and entomopathogens) (KNAAK et al., 2012).

Table 1. Efficiency of undiluted oils $(200 \mu \mathrm{L})$ on eggs and third-instar caterpillars of S. frugiperda.

\begin{tabular}{lcc}
\hline \multirow{2}{*}{ Species } & \multicolumn{2}{c}{ Efficiency (\%) \pm S.E.M. ${ }^{1}$} \\
\cline { 2 - 3 } & Eggs & Caterpillars \\
\hline Copaifera sp. & $68.0 \pm 7.1 \mathrm{a}$ & $100.0 \pm 0.0 \mathrm{a}$ \\
Orbignya phalerata & $14.4 \pm 2.9 \mathrm{~b}$ & $100.0 \pm 0.0 \mathrm{a}$ \\
Carapa guianensis & $64.7 \pm 6.4 \mathrm{a}$ & $97.50 \pm 2.2 \mathrm{a}$ \\
Caryocar brasiliense & $81.1 \pm 7.4 \mathrm{a}$ & $72.50 \pm 9.9 \mathrm{~b}$ \\
Astrocaryum aculeatum & $66.0 \pm 8.8 \mathrm{a}$ & $70.0 \pm 3.7 \mathrm{~b}$ \\
Anadenanthera colubrina & $91.5 \pm 2.6 \mathrm{a}$ & $52.50 \pm 5.6 \mathrm{~b}$ \\
Mauritia flexuosa & $79.1 \pm 8.9 \mathrm{a}$ & $37.50 \pm 15.7 \mathrm{~b}$ \\
Oenocarpus bataua & $57.5 \pm 17.1 \mathrm{a}$ & $12.50 \pm 8.5 \mathrm{c}$ \\
Platonia insignis & $58.2 \pm 3.4 \mathrm{a}$ & $2.50 \pm 2.2 \mathrm{c}$ \\
Pentaclethra macroloba & $30.1 \pm 2.6 \mathrm{~b}$ & $0.0 \pm 0.0 \mathrm{c}$ \\
Vernonia polysphaera & $67.3 \pm 11.1 \mathrm{a}$ & $0.0 \pm 0.0 \mathrm{c}$ \\
\hline
\end{tabular}

Means followed by the same letter within columns do not differ with the Scott-Knott test at 5\% significance. ${ }^{1}$ S.E.M. = standard error of the mean.

The concentration-response mortality curves of

Copaifera sp., O. phalerata, and Carapa guianensis

Rev. Caatinga, Mossoró, v. 29, n. 3, p. 642 - 647, jul. - set., 2016 
oils are presented in Figures $1 \mathrm{~A}, \mathrm{~B}$, and $\mathrm{C}$, respectively. The concentration-response mortality curves varied substantially. The Copaifera sp. oil was the most toxic (Figure $1 \mathrm{~A}$ ). The $\mathrm{LC}_{50}$ varied from 7.50 to $60.84 \%(\mathrm{v} / \mathrm{v})$ (Table 2). The TRs indicated that Copaifera sp. oil was 6.84 and 8.11 times more toxic than $O$. phalerata and Carapa guianensis oils, respectively. The curves for $O$. phalerata and Carapa guianensis had steeper slopes than the curve for Copaifera sp. (Table 2), suggesting that small variations in toxicity could cause $S$. frugiperda to develop resistance to these two oils, as other studies have demonstrated with similar concentrationmortality curves (SOUSA; FARONI; FREITAS, 2014). Additional studies are needed to assess the toxicity of these oils against $S$. frugiperda and the potential for resistance among populations.
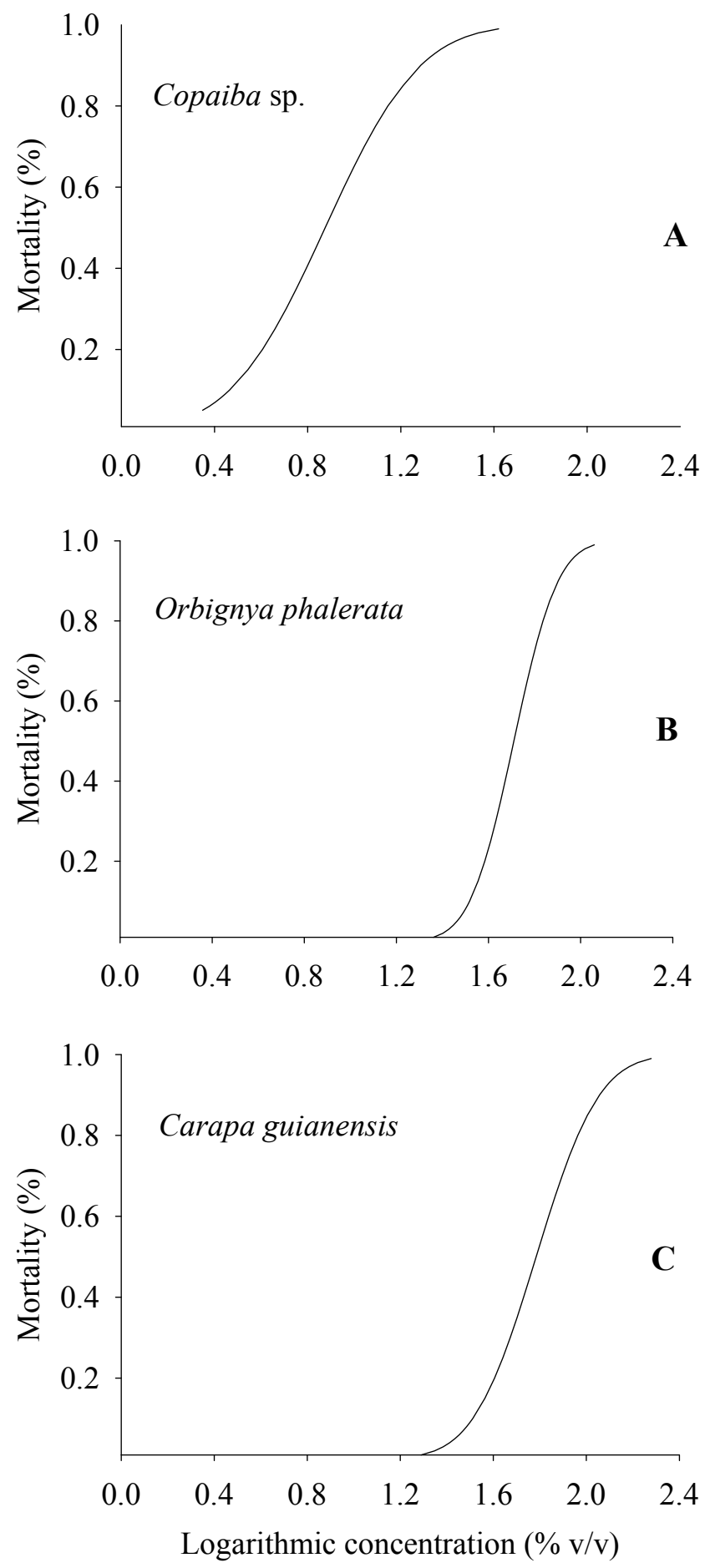

Figure 1. Mortality (\%) of third-instar S. frugiperda caterpillars treated with different concentrations of the oils of Copaifera sp., O. phalerata, and Carapa guianensis. 
A. C. V. SANTOS et al.

Table 2. Toxicity of vegetable oils on third-instar caterpillar of S. frugiperda.

\begin{tabular}{|c|c|c|c|c|c|}
\hline Plant species & Slope \pm S.E.M. $^{1}$ & $\mathrm{LC}_{50}(95 \% \mathrm{FI}) \%(\mathrm{v} / \mathrm{v})$ & $\mathrm{TR}(95 \% \mathrm{CI}) \mathrm{LC}_{50}$ & $\chi^{2}$ & $\mathrm{P}$ \\
\hline Copaifera sp. & $3.12 \pm 0.54$ & $7.50(5.91-9.10)$ & - & 10.06 & 0.43 \\
\hline Orbignya phalerata & $6.66 \pm 0.85$ & $51.31(47.47-55.51)$ & $6.84(5.49-8.54)$ & 24.20 & 0.14 \\
\hline Carapa guianensis & $4.70 \pm 0.69$ & $60.84(53.82-68.21)$ & $8.11(6.40-10.27)$ & 15.56 & 0.34 \\
\hline
\end{tabular}

${ }^{1}$ S.E.M. $=$ standard error of the mean; $\mathrm{LC}_{50}=$ lethal concentration to $50 \%$ of the insects; FI $95 \%=95 \%$ fiducial interval; $95 \% \mathrm{CI}=95 \%$ confidence interval; $\mathrm{TR}=$ Toxic ratio for $\mathrm{LC}_{50} ; \chi^{2}=$ Chi-square test; $\mathrm{P}=$ probability.

Although the Amazon is internationally recognized as a biodiversity hotspot, in-depth studies of the flora as a source of insecticides are quite recent (COITINHO et al., 2006; SILVA et al., 2007; BARBOSA et al., 2011; SARRIA et al., 2011). In this study, most of the 11 oils displayed some activity against $S$. frugiperda eggs. However, Copaifera sp., O. phalerata, and Carapa guianensis oils were the most efficacious against $S$. frugiperda caterpillars.

The toxicity of Copaifera sp. (copaiba) oil demonstrated in this study corroborates the results of Alves et al. (2012). These authors found that methanolic extracts of leaves, bark, and fruits Copaifera were toxic to $S$. frugiperda caterpillars. Barbosa et al. (2011) found that commercial cultivation plots of tomato (Lycopersicon esculentum Mill., Solanaceae), after treatment with a copaiba extract, had reduced numbers of Tuta absoluta (Meyrick, 1917) (Lepidoptera: Gelechiidae) and Bemisia tabaci (Gennadius, 1889) (Hemiptera: Aleyrodidae) 24 and $72 \mathrm{~h}$ after spraying. The toxic effect of copaiba oil has been attributed to its terpenoid fraction (sesquiterpenes and labdanumtype diterpenes) (SILVA et al., 2007).

This is the first report of $O$. phalerata oil toxicity against $S$. frugiperda. Many other species of Arecaceae occur in the Amazon, but there are few studies on potential insecticides within this family. A previous study demonstrated Attalea phalerata Mart. ex Spreng. (Arecaceae) leaf extract toxicity against S. zeamais (SOUZA et al., 2008). The present study demonstrated the toxicity of Carapa guianensis oil against $S$. frugiperda caterpillars. Additionally, Sarria et al. (2011) demonstrated that limonoids isolated from $C$. guianensis arils prolonged caterpillar development and reduced pupa weight.

Plants used in this study were selected from reports on their toxicity, or of their genera and families, against insect pests. All the investigated species demonstrated some effectiveness against $S$. frugiperda. From an integrated management point of view, these results are of fundamental importance because they indicate that insecticidal compounds are present in these species (HAAS et al., 2014). These plants are common in the region and their oils can be easily manufactured, so they may be alternatives to synthetic insecticides for small producers. Locally produced pesticides have lower costs compared to synthetic insecticides, and botanical insecticides may be less damaging to the environment and are easy to prepare through relatively simple techniques (COITINHO et al., 2006; SOUSA; FARONI; FREITAS, 2014).

Copaifera sp., O. phalerata, and Carapa guianensis oils are ideal for incorporation into management programs for $S$. frugiperda in the Amazon region. However, botanical insecticides must be used with care because they can be toxic to mammals via ingestion (ELVIN-LEWIS, 2005), and some natural control agents (parasitoids and predators) are also susceptible to these products (BARBOSA et al., 2011).

\section{CONCLUSIONS}

The majority of the oils displayed moderate insecticidal activity against $S$. frugiperda eggs. Copaifera sp., O. phalerata, and Carapa guianensis oils effectively controlled $S$. frugiperda under laboratory conditions and should be considered as candidates for integrated management programs of corn pests. Additional studies are required to establish the maximum effectiveness of these oils against $S$. frugiperda eggs and caterpillars.

\section{REFERENCES}

ALVES, D. S. et al. Toxicity of copaiba extracts to armyworm (Spodoptera frugiperda). African Journal of Biotechnology, Nairobi, v. 11, n. 24, p. 6578-6591, 2012.

BARBOSA, F. S. et al. Insecticide effects of Ruta graveolens, Copaifera langsdorffii and Chenopodium ambrosioides against pests and natural enemies in commercial tomato plantation. Acta Scientiarum. Agronomy, Maringá , v. 33, n. 1, p. 37-43, 2011.

BAVARESCO, A. et al. Biologia e exigências térmicas de Spodoptera cosmioides (Walk.) (Lepidoptera: Noctuidae). Neotropical Entomology, Londrina, v. 31, n. 1, p. 49-54, 2002.

COITINHO, R. L. B. C. et al. Atividade inseticida de óleos vegetais sobre Sitophilus zeamais MOTS. (Coleoptera: Curculionidae) em milho armazenado. Caatinga, Mossoró, v. 19, n. 2, p. 176-182, 2006. 
CONAB - Companhia nacional de abastecimento. Acompanhamento da safra 2015/2016 - $3^{\circ}$ Levantamento de grãos. Disponível em <http:// www.conab.gov.br/>. Acesso em: 26 de mar. 2016.

COPATTI, C. E.; MARCON, R. K.; MACHADO, M. B. Avaliação de dano de Sitophilus zeamais, Oryzaephilus surinamensis e Laemophloeus minutus em grãos de arroz armazenados. Revista Brasileira de Engenharia Agrícola Ambiental, Campina Grande, v. 17, n. 8, p. 855-860, 2013.

CRUZ, I. et al. Risco potencial das pragas de milho e sorgo no Brasil. Sete Lagoas: Embrapa Milho e Sorgo, 2013. 40 p. (Documentos, 150).

ELVIN-LEWIS, M. P. Safety issues associated with herbal ingredients. In: TAYLOR, S. L. (Ed.). Advances in food and nutrition research. San Diego: Elsevier, 2005. v. 50, cap. 7, p. 219-313.

FARONI, L. R. A.; SOUSA, A. H. Aspectos biológicos e taxonômicos dos principais insetospraga de produtos armazenados. In: ALMEIDA, F. A. C. et al. (Eds.). Tecnologia de Armazenagem em sementes. Campina Grande: UFCG, 2006, v. 1, cap. 7, p. 371-402.

FERREIRA, D. F. Sisvar: a computer statistical analysis system. Ciência e Agrotecnologia, Lavras, v. 35, n. 6, p. 1039-1042, 2011.

FIGUEIREDO, M. L. C.; MARTINS-DIAS, A. M. P.; CRUZ, I. Relação entre a lagarta-do-cartucho e seus agentes de controle biológico natural na produção de milho. Pesquisa Agropecuária Brasileira, Brasília, v. 41, n. 12, p. 1693-1698, 2006.

GUERRA, A. M. N. M. et al. Atividade inseticida de plantas medicinais sobre Callosobruchus maculatus (Coleoptera: Bruchidae), Revista Caatinga, Mossoró, v. 22, v. 1, p. 146-150, 2009.

HAAS, J. et al. Efeito de extratos aquosos vegetais sobre a lagarta-do-cartucho. Arquivos do Instituto Biológico, São Paulo, v. 81, n. 1, p. 79-82, 2014.

KASTEN JUNIOR, P.; PRECETTI, A. A. C. M.; PARRA, J. R. P. Dados biológicos comparativos de Spodoptera frugiperda (J.E. Smith, 1797) em duas dietas artificiais e substrato natural. Revista de Agricultura, Piracicaba, v. 53, n. 1/2, p. 68-78, 1978.

KNAAK, N. et al. Atividade inseticida de extratos de plantas medicinais sobre Spodoptera frugiperda (J.E. Smith) (Lepidoptera: Noctuidae), BioAssay, Piracicaba, v. 7, n. 1, p. 1-6, 2012.
LIMA JÚNIOR, I. $\mathrm{S}$. et al. Seletividade de inseticidas sobre o complexo de predadores das pragas do algodoeiro. Pesquisa Agropecuária Tropical, Goiânia, v. 40, n. 3, p. 347-353, 2010.

MARTINS G. $M$. et al. Inseticidas químicos e microbianos no controle da lagarta-do-cartucho na fase inicial da cultura do milho. Revista Caatinga, Mossoró, v. 22, n. 2, p. 170-174, 2009.

ROBERTSON, J. L.; PREISLER, H. K. Pesticide bioassays with Arthropods. Boca Raton, Florida: CRC Press, 1992. 127 p.

SARRIA, A. L. F. et al. Effect of triterpenoids and limonoids isolated from Cabralea canjerana and Carapa guianensis (Meliaceae) against Spodoptera frugiperda (J. E. Smith). Zeitschrift fur Naturforschung Section c - A Journal of Biosciences, Tubingen, v. 66, n. 5-6, p. 245-250, 2011.

SAS Institute. SAS/STAT(R) 9.3 User's Guide. Disponível em: < http://support.sas.com/ documentation/cdl/en/statug/63962/HTML/default/ viewer.htm\#chap0 toc.htm>. Acesso em: 23 mar. 2011.

SILVA, H. H. G. et al. Larvicidal activity of oil-resin fractions from the Brazilian medicinal plant Copaifera reticulata Ducke (LeguminosaeCaesalpinoideae) against Aedes aegypti (Diptera, Culicidae). Revista da Sociedade Brasileira de Medicina Tropical, Uberaba, v. 40, n. 3, p. 264-267, 2007.

SOUSA, A. H.; FARONI, L. R. A.; FREITAS, R. S Relative toxicity of mustard essential oil insect-pests of stored products. Revista Caatinga, Mossoró, v. 27, n. 2 , p. 222-226, 2014

SOUZA, A. P. et al. Bioprospecting insecticidal compounds from plants native to Mato Grosso do Sul, Brazil. Acta Botanica Brasilica, São Paulo, v. 22, n. 4 , p. 1136-1140, 2008 